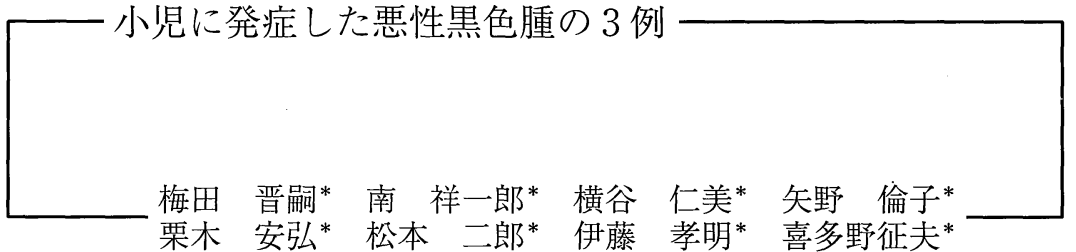

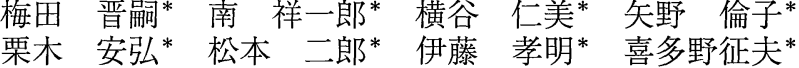

\title{
Three cases of Malignant Melanoma in children
}

Shinji UMEDA* , Shoichiro MINAMI* , Hitomi YOKO'TANI * Noriko YANO* , Yasuhiro KURIKI * , Jiro MATSUMOTO * , Takaaki ITOU * , Yukio KITANO *

* Department of Dermatology, Hyogo Medical College

(Case 1) A 2-year-old girl, there was a blackish eruption that rice size on the inside of her left upper arm at birth. She consulted us alteration of its shape and color from two month ago. We diagnosed it MM by extralesional biopsy and removed it.

(Case 2) A 5-year-old boy, 1 year ago, he noticed blackish eruption on his left sole about $1 \mathrm{~mm}$ diameter. He consulted us gradually spreading of it. We operated extraction of it, and diagnosed it MM.

(Case 3) A 3-year-old girl, when she was 6 months old, a blackish eruption appeared on the third fingertip of her left hand. We diagnosed it MM by extraction of it.

Past 5 years, we experience 20 cases of MM, 3 cases of that is in childhood. [Skin Cancer (Japan) $2001 ; 16: 22-26]$

Key words : Malignant melanoma, Childhood

はじめに

悪性黒色腫（Malignant Melanoma 以下， MM）は比較的若年発症する皮膚悪性腫瘍とし て知られているが，小览の発症例は極めて稀で あるとされている ${ }^{1)}$ 。当科において最近 3 年間 に小児に発症した MMの3 例を経験したが, Spitz nevus との鑑別を含め, 診断, 治療に苦慮 したため，若干の文献的考察を加え報告する。

* 兵庫医科大学皮膚科

症例

症例 1

患 者：2歳，女児

初診: 平成 9 年 5 月 19 日

主 訴: 左上腕内側の自覚症状を欠く黒色皮 疹。

家族歴：特記すべきことなし。

既往歴：特記すべきことなし。

現病歴：生下時より左上腕内側に米粒大の黒 色皮疹があり近医皮膚科にて 3 カ月に一度の割 
合で経過観察されていた。2 カ月前から大きさ が拡大し色調が濃くなったため，当科を紹介さ れ受診した。

初診時現症：左上腕内側に $7 \times 6 \mathrm{~mm}$ 大で, 皮 面よりなだらかに隆起し，軽度鱗屑を伴う黒色 結節があり，辺縁に不整なしみだしを認めた (図 1)。

母斑細胞性母斑，異型母斑， $\mathrm{MM}$ を考え，平 成 9 年 5 月 27 日に全身麻酔下に辺縁より $3 \mathrm{~mm}$ 離して病巣外摘出生検を行った。

病理組織学的所見：過角化があり，表皮内ほ ぼ全層から真皮中層に腫痬細胞よりなる病巣を 認める（図 2 )。

腫瘍を構成する細胞は，核の大小不同を認 め，核小体の目立つ比較的大型の異型細胞であ り，一部では，これらの細胞が胞巣を形成して いた。メラニン色素が病巣全層にわたり不規則 に認められ，リンパ球浸潤を伴っていたが，力 ミノ小体はみられなかった（図 3)。HMB-45 陽 性， S100 蛋白陽性であった。以上より $\mathrm{MM}$ (pT2, tumor thickness 0.82) と診断した。

治療および経過：平成 9 年 6 月 5 日に, 全身 麻酔下にて前回の縫合創より $2.5 \mathrm{~cm}$ はなし筋膜 上にて拡大摘出を行い，鼠径部よりの全層植皮 術を施行した。一般臨床検査, 腹部エコー, 胸 部レントゲン，CTにて異常を認めず，術後 3 年 3 力月の間，再発，転移を認めていない。

症例 2

患 者: 5 歳, 男児

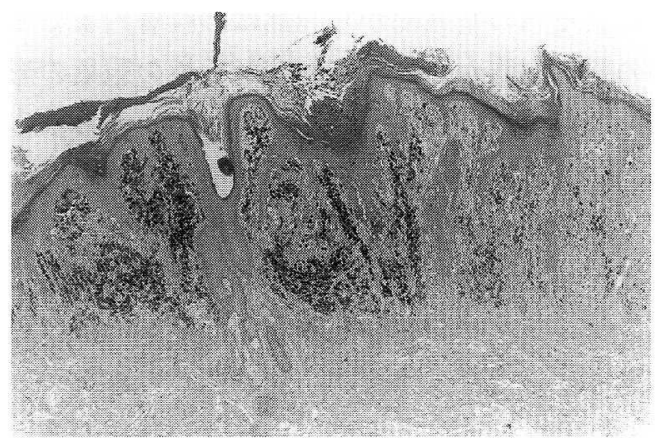

図 2. 症例 1 H.E. 染色 弱拡大像（20 倍）
初 診: 平成 11 年 8 月 27 日

主 訴：左足底の自覚症状を欠く黒色皮疹。 家族歴：特記すべきことなし。

既往歴：特記すべきことなし。

現病歴： 1 年位前から左足底内側に $1 \mathrm{~mm}$ 程 度の黒色皮疹があり，徐々に拡大してきたため 当科を受診した。それ以前に同部には皮疹を認 めていなかった。

初診時現症: 左足底内側縁に $5 \times 3 \mathrm{~mm}$ の中央 に盛り上がりのある黑色丘疹を認めた（図 4，5 )。母斑細胞性母斑， MM を考え，平成 11 年 9 月 13 日に局所麻酔下に辺縁より $5 \mathrm{~mm}$ 離し摘出術を行った。

病理組織学的所見：主に表皮基底部に腫瘍細 胞よりなる胞巣形成を認められたが，一部は表 皮上層にも胞巣が存在した。また，経表皮性に メラニンの排出がみられ，真皮上層にはメラ， ファージが多数みられ，リンパ球浸潤も認めた

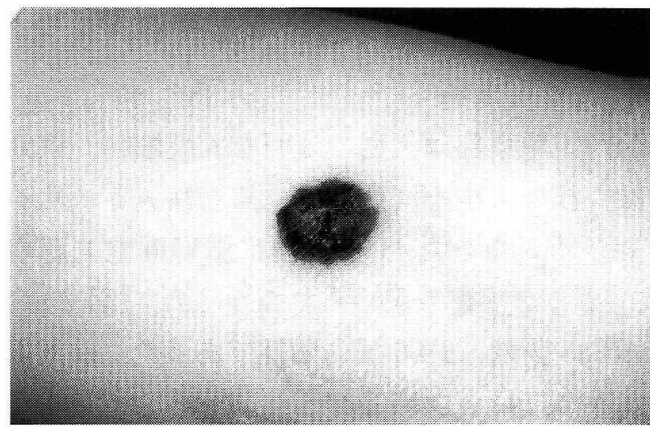

図 1 ，症例 1 左上腕内側

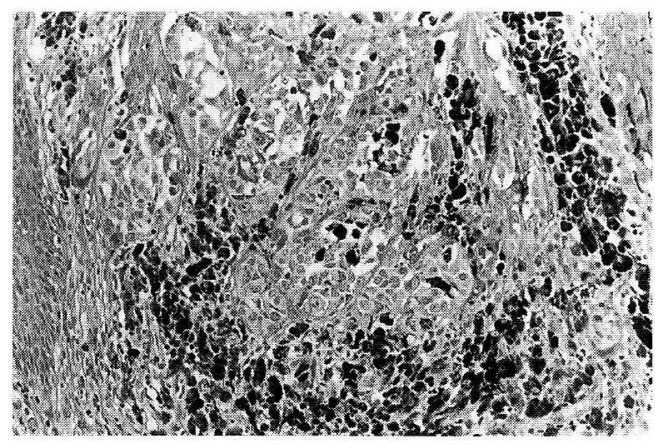

図 3. 症例 1 H.E. 染色 強拡大像 (200 倍) 


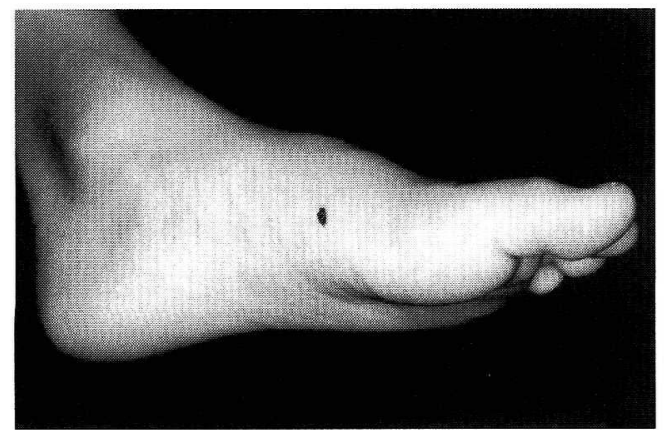

図 4. 症例 2 左足底内側

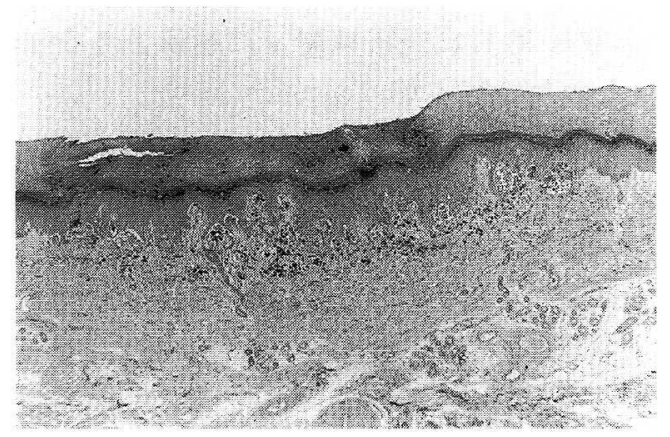

図 6. 症例 2 H.E.染色 弱拡大像 (20 倍)

（図 6)。胞巣部は大型で淡明な異型細胞，核分 裂像，核の大小不同を認め，孤立性メラノサイ 卜も多くみられた。真皮内に腫瘍細胞を認め ず，カミノ小体も認められなかった（図７）。 HMB-45 陽性, S100 蛋白陽性であった。以上よ り MM in situ と診断した。

経 過：一般臨床検査, 胸部レントゲン, $\mathrm{Ga}$ シンチにおいて異常はなかった。摘出より 11 カ 月たった現在も再発，転移を認めていない。

\section{症例 3}

患 者: 3 歳, 女览

初 診: 平成 11 年 12 月 13 日

主 訴: 左第 3 指指尖部の自覚症状を欠く黒 色皮疹。

家族歴：特記すべきことなし。

既往歴：特記すべきことなし。

現病歴：生後 6 力月頃, 左第 3 指指尖部に自 覚症状を欠く黒色皮疹があるのに気付き拡大し

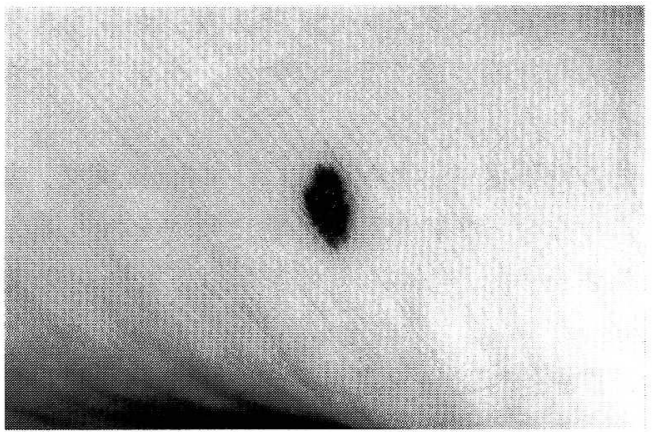

図 5. 症例 2 左足底内側 拡大像

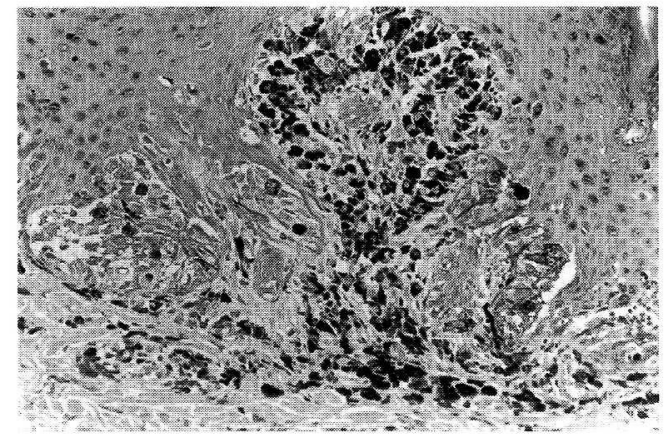

図 7. 症例 2 H.E.染色 強拡大像 (200倍)

てきたため，近医内科を受診し，当科を紹介さ れた。生下時には皮疹は認めていなかった。

初診時現症：左第 3 指指尖部爪縁から一部 爪甲下にかけて $4 \times 3 \mathrm{~mm}$ 大の境界不明瞭な黒 色斑を認める（図 8 ）。母斑細胞性母斑を考え， 平成 12 年 1 月 12 日に局所麻酔下に辺縁より $1 \mathrm{~mm}$ 離して摘出した。

病理組織学的所見: 表皮肥厚, 表皮突起の延 長と表皮内の基底部から一部は顆粒層内まで大 小の腫瘍細胞加らる左右非対称性の胞巣の形 成を認め，角層内にメラニンの排出がみられる (図 9)。胞巣部は, 大型で淡明な異型細胞より 成り，核の大小不同，核分裂像を認め，表皮基 底層にメラノサイトの増生を認めた。真皮内に はメラノファージが多数みられ, リンパ球の浸 潤をも認めたが，カミノ小体は認められなかっ た（図 10）。HMB-45 陽性, S100 蛋白陽性であっ た。以上より MM in situ と診断した。 


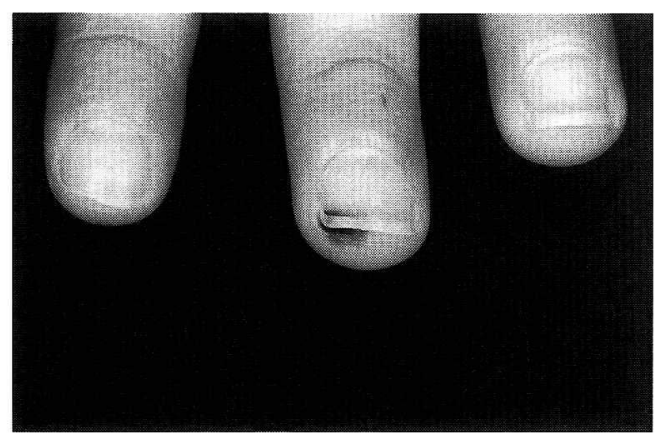

図 8 . 症例 3 左第 3 指指尖部

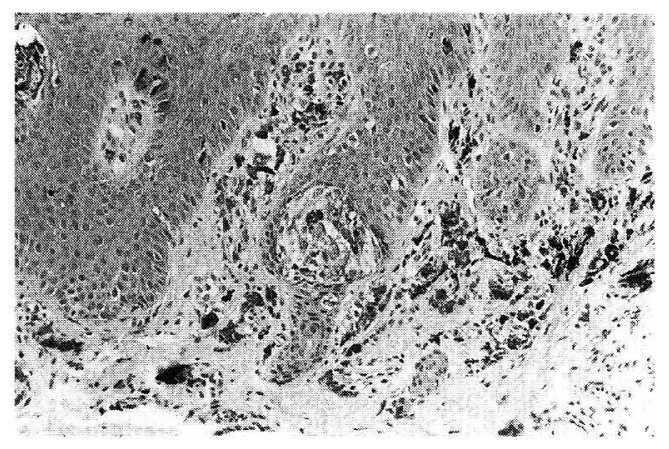

図 10. 症例 3 H.E. 染色 強拡大像 (200 倍)

治療および経過 : 病巣内切除されているこ と, $1 \mathrm{~cm}$ はなすと全周に及ぶことより, 平成 12 年 1 月 20 日に全身麻酔下にて左第 3 指中節骨切 断術および断端形成術を施行した。また一般臨 床検査, 胸部レントゲン, 頭部, 胸部 CT, Ga シンチにおいて異常は認められなかった。術後 7 カ月の間, 再発, 転移を認めていない。

\section{考察}

欧米では1995年の Whiteman ら 2 の統計によ ると小児の MM は全 MM の $2 \%$ であり, 極めて 稀とされている。しかし，その予後は概して悪 く,成人 MMに拈ける予後と変わらないとされ ている ${ }^{3)}$ 。

本邦における小児期に発症した皮膚原発 MM の症例は村澤らによると 15 歳以下では 62 例あ り, 平均年齢 6.3 歳で性差はないとされている。

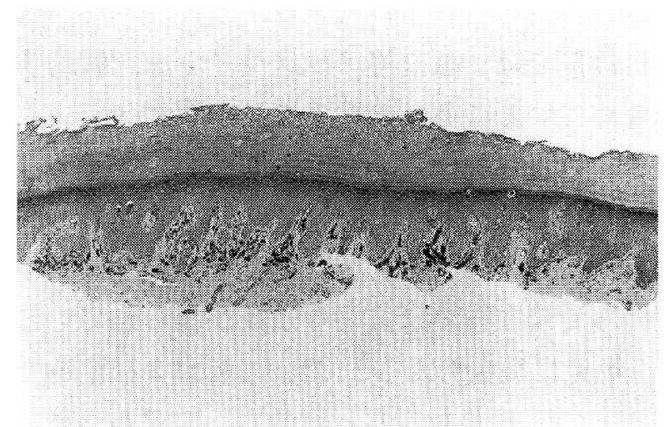

図 9. 症例 3 H.E. 染色 弱拡大像（20 倍）

発生部位別にみると体幹部が 22 例と一番多く, 発生母地としては先天性色素性母斑を有してい るものが 23 例と最も多いと報告されている。 また同様に小児 $\mathrm{MM} の$ 本邦報告例をまとめた 神戸ら ${ }^{4)}$ の集計によると，巨大色素性母斑以外 から生じた 23 例の MM では組織型として結節 型のものが 3 分の 2 を占めて抢り, それらは予 後も悪いと述べている。これらの巨大色素性母 斑以外から生じた MM では色素性乾皮症から 生じた 2 例を除くと体幹部 2 例 (8.7\%)，四肢 15 例 $(65.2 \%)$ となり明らかに体幹部が少なく四 肢に多いことも判る。さらに 7 例 (30.4\%) は 四肢末端部に発生して㧍り，本邦に扔ける成人 の発生率とほぼ同じであることも読み取れる。 今回, 我々が報告した 3 例共, 四肢（上腕, 足 底，手指）に発生しており，先に述べた傾向に 準じている。

小児 $\mathrm{MM}$ の鑑別疾患として重要なものの1つ にSpitz nevus が挙げられる。自験例においても 鑑別，治療方針に非常に苦慮した。Spitz nevus の特徴は，病変が全体として左右対称性である こと, 表皮内病変の辺縁の境界が明瞭であるこ と, 表皮中層以上にメラノサイトの浸潤がみら れないこと，腫瘍深部に細胞分裂像がみられな いこと，孤立性メラノサイトが比較的少ないこ と，カミノ小体がみられること等 ${ }^{5)}$ が挙げられ ている。いずれにせよ，その症例，症例におい て，これらの所見の組み合わせにより MM と Spitz nevusを鑑別しなければならないことに 
なる。

自験例では，孤立性メラノサイトを比較的多 く認めていること, 表皮上層にも異型メラノサ イトがみられていること, カミノ小体を認めな かったこと等より MM と診断した。

自験例は大きさが比較的小さな症例で手術治 療のみで現在までは良好な予後が得られている が，小児に発生した MM は，診断および治療を 行う上で困難であることが多く, 慎重かつ積極 的に行わなければならないと考える。

\section{文献}

1) Nicholas. C. Saenz, et al. : Childhood Melanoma Survival, Cancer, 85, 3, 750-754, 1999.

2) Whiteman. D., et al. : Incidence of cutaneous childhood melanoma In Queensland, Int. J. Cancer, 63, 765-768, 1995.

3）村澤章子, 他：小览皮膚覀性黒色腫の治療経験押 よび本邦報告例の検討，日形会誌，18,652-661， 1998.

4）神戸直智，他：12 歳女児にみられた悪性黒色腫の 報告と本邦小児悪性黑色腫 60 例の検討, 臨皮, 50 , 4, 303-306, 1996.

5）原一夫, 大橋勝 : メラノサイト病変, 平川宗信, 1 版, 名古屋大学出版会, 名古屋, 1997, 30-113. 